\title{
The Effectiveness of Musa paradisiaca l. Peel Carbon Thickness as a Filtering Media for Decreasing the Levels of Iron (fe) in Ground Water
}

\author{
Authors \\ Atang Saputra $^{1^{*}}$, Aris Budianto ${ }^{2}$, Dea Fadila Tinura ${ }^{3}$ \\ 1,2,3 Jakarta Ministry of Health Polytechnic \\ *Corresponding Author \\ Atang Saputra ${ }^{1}$ Aris \\ Email: atangdepkes@gmail.com
}

\begin{abstract}
Background: Provision of clean water can be obtained from various sources, whether groundwater or surface water. Groundwater often contains high levels of iron ( $\mathrm{Fe}$ ). Many residents are forced to use water, which in terms of quality does not meet the requirements, one of which is the chemical requirements in the form of high content of iron ( $\mathrm{Fe}$ ) which can cause diarrhea, anemia, kidney damage which ends in death.

This study aims to determine the effectiveness of using banana peel of Musa paradisiaca L. as a filtration medium for decreasing iron content in groundwater.

Methods: This research is experimental to determine the effectiveness of thickness of Musa paradisiaca L. banana peel activated carbon in reducing iron $(\mathrm{Fe})$ levels in groundwater. This research was conducted at the Jakarta Health Ministry Polytechnic Workshop. Samples used \pm 120 liters originated from electric pump wells treated by using Musa paradisiaca L. banana peel activated carbon filter with variations in the thickness of $0 \mathrm{~cm}$ as control / without activated carbon of Musa paradisiaca L. banana peel, $30 \mathrm{~cm}, 45 \mathrm{~cm}$, $60 \mathrm{~cm}$, and $75 \mathrm{~cm}$ with 2 liters per minute flow discharge. Then five treatments were carried out with three repetitions in each treatment.

Result: Research results revealed that iron $(\mathrm{Fe})$ content before processing by filtration method using Musa paradisiaca L. banana peel carbon media was $2.8 \mathrm{~cm} / \mathrm{L}$. Iron ( Fe) levels allowed for clean water quality requirements according to the Minister of Health Regulation No. 32 of 2017 was $1.0 \mathrm{mg} / \mathrm{L}$. The result indicated the content of water had exceeded the standard.

Conclusion: Of the five treatments, the most effective in reducing iron $(\mathrm{Fe})$ is at a thickness of $30 \mathrm{~cm}$ because with a small thickness (low) it has been able to reduce the below average levels of maximum permissible.

Keyword: Clean water, effectiveness, filtration, Musa paradisiaca L. banana peel.
\end{abstract}

\section{Introduction}

Metal content in groundwater such as iron $(\mathrm{Fe})$ is found in the groundwater / artesian well. If people are still using groundwater containing iron levels high without any processing first, it will cause diarrhea, anemia, and kidney damage, damage to the equipment and clothes that are white to yellow spots caused by oxidized iron bacteria that cause the color to the garments (Yang,2012).

The Pancoran Mas area is an area built in the swamp area adjacent to the Lio swamp. Communities in the area using clean water from 
groundwater sources (dug wells) for their daily needs. Based on the results of the field survey physically the water is yellow, smelly and tasteless. The quality of groundwater testing in one of the groundwater sources in the area used by residents of Depok Village Pancoran Mas District, Depok City, obtained the initial examination results of $2.8 \mathrm{mg} / \mathrm{L}$. The results received exceed the permissible standard quality of $1 \mathrm{mg} / \mathrm{L}$ because it can cause eye and peel irritation. So, the water used for daily needs must be processed first. One of the processing of clean water is filtration (filtering), the people whose clean water has iron $(\mathrm{Fe})$ levels above the prescribed standards, the public can make simple filtration devices.

The waste of Musa paradisiaca L. banana peel is processed into activated carbon as a filter medium. So far, the waste of Musa paradisiaca $L$. banana peel has been left unchecked, even though it is still possible to use it with biochemical content including cellulose, hemicellulose, chlorophyll pigment and pectin substances containing galacturonic acid, arabinose, galactose, and rhamnose. Galacturonic acid is a chemical compound that can bind metal ions which are functional groups of carboxyl sugars which play a role in the adsorption process (Olieviera et al., 2016).

\section{Methods}

This type of research was experimental to determine the effectiveness of thickness of Musa paradisiaca $L$. banana peel activated carbon in reducing iron $(\mathrm{Fe})$ levels in clean water. This research was conducted at the Jakarta Health Ministry Health Department Polytechnic II Workshop. Checking the water quality of the sample was carried out in the Chemistry Laboratory of the Department of Environmental Health. The population of this study was clean water originating from bore wells / electric pump wells in the housing of Depok Village Pancoran Mas District, Depok City. The initial examination revealed that the water contained iron $(\mathrm{Fe})$, which was $2.8 \mathrm{mg} / \mathrm{L}$. The samples taken in this study were clean water from electric wells/pump wells from household as much as 120 liters for three replications. The research design used was the design of One Group Pret Posttest with three repetitions of each treatment.

\section{Results and Discussion}

Based on the results of examinations conducted at the Chemistry Laboratory of the Department of Environmental Health, Health Ministry Polytechnic, Jakarta II, the content of Iron (Fe) in groundwater before treatment was $2.8 \mathrm{mg} / \mathrm{L}$. In accordance with the Minister Of Health Regulation No. 32 for the chemical parameters of one of the iron $(\mathrm{Fe})$, which is the maximum permissible level of only $1 \mathrm{mg} / \mathrm{L}$. Physically the water is brownish yellow in color, smells of rust and leaves brown precipitate around the bathroom floor. The water used is sourced from groundwater in the former swamp area which has a high water content of iron (Fe).

Table 3.1 Average levels of iron $(\mathrm{Fe})$ in groundwater before and after treatment with activated carbon of banana peel

\begin{tabular}{|c|c|c|c|c|c|c|}
\hline \multirow[t]{2}{*}{ No } & \multirow[t]{2}{*}{$\begin{array}{l}\text { The thickness of Peel } \\
\text { Activated Carbon Musa } \\
\text { paradisiaca L. Banana (cm) }\end{array}$} & \multirow[t]{2}{*}{$\begin{array}{c}\text { Iron }(\mathrm{Fe}) \\
\text { Before } \\
\text { Processed }(\mathrm{Mg} \\
\text { / L) }\end{array}$} & \multicolumn{3}{|c|}{$\begin{array}{c}\text { Iron (Fe) After Processed } \\
(\mathrm{Mg} / \mathrm{L})\end{array}$} & \multirow[t]{2}{*}{$\begin{array}{c}\text { Average Level of Iron } \\
\text { (Fe) After Treatment } \\
(\mathrm{Mg} / \mathrm{L})\end{array}$} \\
\hline & & & 1 & 2 & 3 & \\
\hline 1 & 0 & 2.8 & 1.67 & 1.68 & 1.66 & 1.67 \\
\hline 2 & 30 & 2.8 & 1.02 & 0.79 & 0.73 & 0.84 \\
\hline 3 & 45 & 2.8 & 0.76 & 0.77 & 0.73 & 0,75 \\
\hline 4 & 60 & 2.8 & 0.74 & 0.78 & 0.84 & 0.78 \\
\hline 5 & 75 & 2.8 & 0.73 & 0.87 & 0.77 & 0.79 \\
\hline
\end{tabular}


Based on table 3.1 it is known the results of measurements of iron $(\mathrm{Fe})$ levels before treatment of $2,8 \mathrm{mg} / \mathrm{L}$ and after treatment using variations in the thickness of activated carbon Musa paradisiaca $L$. banana peel obtained an average decrease in iron $(\mathrm{Fe})$ thickness of $0 \mathrm{~cm}$ by $1.67 \mathrm{mg}$ / L, at a thickness of $30 \mathrm{~cm}$ by $0.84 \mathrm{mg} / \mathrm{L}$, at a thickness of $45 \mathrm{~cm}$ at $0.75 \mathrm{mg} / \mathrm{L}$, at a thickness of $60 \mathrm{~cm}$ at $0.78 \mathrm{mg} / \mathrm{L}$, at a thickness of $75 \mathrm{~cm}$ at $0.79 \mathrm{mg} / \mathrm{L}$.

Iron $(\mathrm{Fe})$ levels in clean water should not reach zero because the presence of iron $(\mathrm{Fe})$ in water serves the body's metabolism. In the body, small amounts of iron $(\mathrm{Fe})$ are useful for the formation of red blood cells. According to Mahapatra
(2012), in the human body need the content of iron $(\mathrm{Fe})$ but also dose is too large can cause health problems such as damage to the intestinal wall, irritation. In addition to health problems if the content of iron $(\mathrm{Fe})$ in groundwater is more than $1 \mathrm{mg} / \mathrm{L}$ is a technical problem and the physical problems of water quality are contaminated such as smelling rust, yellow and felt, if used to wash clothes white, it will cause stains on clothes. Iron $(\mathrm{Fe})$ is corrosive; therefore if groundwater containing high iron content will leave deposits in the drain pipe and leave stains on the walls or reservoirs (Gupta,2009).

Table 3.2 Percentage Decrease in Iron (Fe) Levels in Clean Water with Variations in Thickness of Peel Activated Carbon of Musa paradisiaca L. Bananas

\begin{tabular}{cccccc}
\hline No & $\begin{array}{c}\text { The thickness of Active } \\
\text { Carbon PeelMusa } \\
\text { paradisiaca L. Banana } \\
(\mathbf{C m})\end{array}$ & $\begin{array}{c}\text { Iron (Fe) Before } \\
\text { Processed (Mg / } \\
\text { L) }\end{array}$ & $\begin{array}{c}\text { Flat Iron (Fe) } \\
\text { Level After } \\
\text { Processing (Mg / } \\
\text { L) }\end{array}$ & $\begin{array}{c}\text { The difference } \\
\text { in Average } \\
\text { Decrease (Mg / } \\
\text { L) }\end{array}$ & $\begin{array}{c}\text { Percentage } \\
\text { of Iron } \\
(\mathbf{F e})\end{array}$ \\
\hline 1 & 0 & 2.8 & 1.67 & 1.13 & Level40.36 \\
2 & 30 & 2.8 & 0.84 & 1.96 & 70 \\
3 & 45 & 2,8 & 0.75 & 2.05 & 73.21 \\
4 & 60 & 2.8 & 0.78 & 2.02 & 72.41 \\
5 & 75 & 2.8 & 0.79 & 2.01 & 71.78 \\
\hline
\end{tabular}

Based on table 3.2 the results were obtained the decrease in iron content $(\mathrm{Fe})$ after treatment using variations in the thickness of carbon activated Musa paradisiaca $L$. banana peel with the highest percentage reduction was at a thickness of $45 \mathrm{~cm}$ with an average percentage decrease of $73.21 \%$. Based on the results of research that has been carried out using variations in the thickness of activated carbon on the Musa paradisiaca $L$. banana peel, it can be seen that the activated carbon of Musa paradisiaca L. banana peels can absorb metal content in water such as iron (Fe) (Maet al., 2012). This can be proven from the results of experiments conducted, obtained a decrease in levels of iron $(\mathrm{Fe})$ in groundwater to $73.21 \%$ or $0.75 \mathrm{mg} / \mathrm{L}$ after treatment with groundwater before treatment.
The decrease in iron $(\mathrm{Fe})$ levels with the presence of banana peel activated carbon-containing several biochemical components, including cellulose, hemicellulose and pectin substances containing galacturonic acid, arabinose, galactose, and rhamnose. Iron content in groundwater is absorbed in the pores of activated carbon to saturation so that the level of iron $(\mathrm{Fe})$ in the water decreases. Musa paradisiaca $L$. banana peel has a large enough surface area so that it has a good adsorption power of iron $(\mathrm{Fe})$ in water. Also, the adsorption power is increased by an activation process which functions to increase the absorption of activated carbon so that the results are more effective (Achak,2009). 
Table 3.3 Effectiveness of variations in the thickness of activated carbon of Musa paradisiaca L. banana peel in decreasing levels of iron $(\mathrm{Fe})$ in clean water

\begin{tabular}{ccccc}
\hline No & $\begin{array}{c}\text { The thickness of Activated } \\
\text { Carbon Peel of Banana Musa } \\
\text { paradisiaca } \mathbf{L .}(\mathbf{C m})\end{array}$ & $\begin{array}{c}\text { Average Level of Iron } \\
(\mathbf{F e}) \text { After Processing } \\
(\mathbf{M g} / \mathbf{L})\end{array}$ & $\begin{array}{c}\text { Standard of } \\
\text { Clean } \\
\text { Water }\end{array}$ & Effectiveness \\
\hline 1 & 0 & 1.67 & 1 & Not Effective \\
2 & 30 & 0.84 & 1 & Effective \\
3 & 45 & 0.75 & 1 & Effective \\
4 & 60 & 0.78 & 1 & Effective \\
5 & 75 & 0.79 & 1 & Effective \\
\hline
\end{tabular}

Based on table 3.3 it was found that the results of the decrease in iron $(\mathrm{Fe})$ after treatment using Musa paradisiaca $L$. banana peel activated carbon has effectively reduced levels of iron $(\mathrm{Fe})$ to 0.75 mg / L. based on the Minister Of Health Regulation No. 32 of 2017 concerning "Environmental Health Standard Quality Standards and Water Health Requirements for Sanitary Hygiene Needs, Swimming Pools, Solus Per Aqua, and Public Baths." Namely, the quality standard is permitted only $1 \mathrm{mg} / \mathrm{L}$.

Iron $(\mathrm{Fe})$ levels in groundwater after going through the filter treatment process with a discharge of 2 liters per minute using only gravel and palm fiber media (without Musa paradisiaca L. banana peel activated carbon) with three repetitions with an hour contact time can reduce the average iron content amounting to $1.13 \mathrm{mg} / \mathrm{L}$ or $40.36 \%$. At a thickness of $30 \mathrm{~cm}$ the activated carbon of Musa paradisiaca L. banana peel lowers the average iron content of $1.96 \mathrm{mg} / \mathrm{L}$ or $70 \%$, at a thickness of $45 \mathrm{~cm}$ the activated carbon of Musa paradisiaca $L$. banana peel can reduce iron levels by an average of $2.05 \mathrm{mg} / \mathrm{L}$ or $73,21 \%$, at $60 \mathrm{~cm}$ thickness of activated carbon Musa paradisiaca $L$. banana peel can reduce the average iron content of $2.02 \mathrm{mg} / \mathrm{L}$ or $72.41 \%$, at a thickness of $75 \mathrm{~cm}$ the activated carbon of Musa paradisiaca L. banana peel can reduce the average iron content by 2,01 $\mathrm{mg} / \mathrm{L}$ or $71.78 \%$.

In other words, the thicker the media used, the higher the iron content that can be absorbed, and vice versa, if the activated carbon media of Musa paradisiaca $L$. banana peel is used a little, then a small amount of iron will be absorbed. But in this study with the highest thickness, there was no significant reduction compared to the thickness of the activated carbon with less thickness. Because the pipe with the thickest media thickness has mostly flowed with water as a step to clean the media so that the ability to absorb iron $(\mathrm{Fe})$ is reduced, the volume of water needed is quite large, but the ability to absorb it has decreased. However, even though the thickness is the highest but the yields obtained are smaller than the smaller thickness, there is still a decrease to below the maximum permissible level.

In the control treatment / without activated carbon Musa paradisiaca L. banana peel (Control) decreased but the results obtained on average after treatment was $1.67 \mathrm{mg} / \mathrm{L}$, the results obtained did not meet the requirements (ineffective) when compared with the quality standards according to Regulation Of The Minister Of Health No. 32 Of 2017 concerning "Standard Standards for Environmental Health Quality and Health Requirements for Water for Sanitary Hygiene Needs, Swimming Pools, Solus Per Aqua and Public Baths." Which states that iron (Fe) permitted in groundwater is $1 \mathrm{mg} / \mathrm{L}$.

According to Mopung (2011), useful is the achievement of results that are following the objectives as determined. Based on the theory of effectiveness according to $\mathrm{Li}$ et al (2017), it is a measure that states how far (quantity, quality, and time) has been reached. Where the more significant the percentage produced the higher the effectiveness. From the results of the study, it was found that the thickness of the activated carbon of Musa paradisiaca $L$. banana peel was the most 
effective in reducing iron $(\mathrm{Fe})$, which was $30 \mathrm{~cm}$ thickness $(0.84 \mathrm{mg} / \mathrm{L})$, for a higher thickness the results were valid. However, with fewer thicknesses, it can reduce iron (Fe) levels below the maximum permissible levels.

It was declared effective because after being compared with the regulations stipulated, namely Regulation Of The Minister Of Health No 32 the Year 2017 concerning "Standard of Environmental Health Quality Standards and Water Health Requirements for Sanitary Hygiene Needs, Swimming Pools, Solus Per Aqua and Public Baths, which states that iron content ( Fe) which is allowed in groundwater is $1 \mathrm{mg} / \mathrm{L}$.

\section{Conclusion}

The reduction in iron $(\mathrm{Fe})$ content using variations in the thickness of activated carbon in Musa paradisiaca $L$. banana peel obtained a decrease in iron $(\mathrm{Fe})$ content, thickness of $0 \mathrm{~cm}$ (without using Musa paradisiaca $L$. banana peel activated carbon) can reduce iron levels by $1.13 \mathrm{mg} / \mathrm{L}$ (40, $36 \%$ ), a thickness of $30 \mathrm{~cm}$ of activated carbon on Musa paradisiaca $L$. banana peel can reduce iron (Fe) levels by $1.96 \mathrm{mg} / \mathrm{L}$ (70\%), $45 \mathrm{~cm}$ thickness of activated carbon of Musa paradisiaca $L$. banana peel can reduce iron (Fe) by $205 \mathrm{mg} / \mathrm{L}$ $(73.21 \%)$, the thickness of $60 \mathrm{~cm}$ of activated carbon in Musa paradisiaca L. banana peel can reduce iron (Fe) levels by $2.02 \mathrm{mg} / \mathrm{L}(72.41 \%)$, the thickness of $75 \mathrm{~cm}$ of activated carbon in banana peel can reduce iron (Fe) level of $2.01 \mathrm{mg}$ / L (71.78\%)

The most effective thickness of activated carbon of banana peel is $30 \mathrm{~cm}$ thickness which has been effective in reducing iron (Fe) levels below the maximum permissible groundwater according to the Minister Regulation Health No 322017 concerning "Quality Standards for Environmental Health and Periyar Water for Sanitation, Swimming Pool, Purposes Solus Per Aqua and Public Baths. "the maximum permissible level is only $1 \mathrm{mg} / \mathrm{L}$. By giving a decrease in iron (Fe) levels to $0.84 \mathrm{mg} / \mathrm{L}(70 \%)$.

\section{References}

1. Achak, M., Hafidi, A., Ouazzani, N., Sayadi, S. and Mandi, L., 2009. Low-cost bio absorbent "banana peel" for the removal of phenolic compounds from olive mill wastewater: Kinetic and equilibrium studies. Journal of hazardous materials, 166(1), pp.117-125.

2. Gupta, A., Chauhan, V.S. and Sankararamakrishnan, N., 2009. Preparation and evaluation of ironchitosan composites for removal of As (III) and As (V) from arsenic contaminated real life groundwater. Water Research, 43(15), pp.3862-3870.

3. Li, F., Qin, F., Zhang, K., Fang, J., Lai, Y. and Li, J., 2017. Hierarchically porous carbon derived from banana peel for lithium-sulfur battery with high areal and gravimetric sulfur loading — Journal of Power Sources, 362, pp.160-167.

4. Mahapatra, G., 2012. A study on soil, water, and meat, relation in residues of heavy-metal a different perspective (Doctoral dissertation, Kolkata).

5. Ma, J., Huang, D., Zou, J., Li, L., Kong, Y. and Komarneni, S., 2015. Adsorption of methylene blue and Orange II pollutants on activated carbon prepared from banana peel. Journal of Porous Materials, 22(2), pp.301-311.

6. Mopoung, S., 2011. The occurrence of a carbon nanotube from banana peel activated carbon mixed with mineral oil International Journal of Physical Sciences, 6(7), pp.1789-1792.

7. Oliveira, T.Í.S., Rosa, M.F., Cavalcante, F.L., Pereira, P.H.F., Moates, G.K., Wellner, N., Mazzetto, S.E., Waldron, K.W. and Azeredo, H.M., 2016. Optimization of pectin extraction from banana peels with citric acid by using response surface methodology - food Chemistry, 198, pp.113-118. 
8. Yang, F., Shi, B., Gu, J., Wang, D. and Yang, M., 2012. Morphological and physicochemical characteristics of iron corrosion scales formed under different water source histories in a drinking water distribution system. Water Research, 46(16), pp.5423-5433. 